\title{
A COMPARATIVE LOOK AT DIVORCE, LAWS AND THE BEST INTERESTS OF THE CHILD AFTER PARENTAL SEPARATION IN BRAZIL AND ENGLAND
}

\author{
UM OLHAR COMPARATIVO SOBRE DIVÓRCIO, LEIS E OS \\ MELHORES INTERESSES DA CRIANÇA APÓS A SEPARAÇÃO DOS \\ PAIS NO BRASIL E NA INGLATERRA
}

Recebimento: 24 maio 2020

Aceitação: 22 abr. 2021

\begin{abstract}
Josimar Antônio de Alcântara Mendes
Doctoral researcher in Psychology; mestre em Psicologia Clínica e Cultura

Afiliação institucional: University of Sussex (United Kingdom)

Lattes iD: http://lattes.cnpq.br/2125081512755024

Email: josimards@gmail.com

Thomas Ormerod

Ph.D in Psychology

Afiliação institucional: University of Sussex (United Kingdom)

iD: https://profiles.sussex.ac.uk/p350668-thomas-ormerod

Email:T.Ormerod@sussex.ac.uk
\end{abstract}

\begin{abstract}
Como citar este artigo / How to cite this article (informe a data atual de acesso / inform the current date of access):
MENDES, Josimar Antônio de Alcântara; ORMEROD, Thomas. A comparative look at divorce, laws and the best interests of the child after parental separation in Brazil and England. Revista da Faculdade de Direito UFPR, Curitiba, v. 66, n. 2, p. 95-126, maio/ago. 2021. ISSN 2236-7284. Disponível em: https://revistas.ufpr.br/direito/article/view/74001. Acesso em: 31 ago. 2021. DOI: http://dx.doi.org/10.5380/rfdufpr.v66i2.74001.
\end{abstract}

\begin{abstract}
Assuring the best interests of the child (BIC) in child custody cases after parental separation is a hard task for the legal actors involved. Many factors play a role by modifying and shaping legal decisionmaking processes. Depending on the dynamic of such factors, the decision-making process can be more or less difficult. This paper presents a narrative review that offers a comparative look at Brazil's and England's legal processes and contextual issues involved in child custody cases after parental separation. The paper discusses understandings and guidance regarding the BIC as well as regulations concerning the relationship between children and their parents and divorce. The paper reveals that legal and cultural issues can shape those understandings and guidance, and can lead to significant differences in judicial process concerning child custody in each country. In particular, cultural and legal differences between the English common law and the Brazilian civil law systems (e.g., conceptions towards 'custody'; parental responsibility; custodial arrangement; and the judicial process in child custody cases) can impact the decision-making process and the child's best interests.
\end{abstract}




\section{KEYWORDS}

Divorce. Child Custody Dispute. Child arrangements. Civil law. Common law.

\section{RESUMO}

A preservação dos melhores interesses da criança/adolescente (MICA) nos casos de disputa de guarda e convivência após a separação conjugal é uma tarefa difícil para os atores jurídicos envolvidos nesses casos. Existem alguns fatores que desempenham um papel significativo nesse contexto, ao modificar e/ou moldar o processo legal e o processo de tomada de decisão. Assim, a depender da dinâmica apresentada por esses fatores, o processo de tomada de decisão pode ser mais ou menos difícil. Este artigo apresenta uma revisão narrativa de literatura que teve como objetivo trazer uma visão comparativa entre os processos legais no Brasil e na Inglaterra, bem como questões contextuais envolvidas na disputa de guarda após a separação conjugal. Nesse sentido, são discutidos entendimentos e orientações legais quanto aos MICA, assim como regulações legais relativas à relação parento-filial e divórcio nos dois países. Revela-se que questões legais e culturais podem moldar esses entendimentos e orientações, o que pode levar a diferenças significativas no processo judicial referente à guarda de crianças em ambos os países. Assim, destacam-se e se discutem diferenças culturais e jurídicas relevantes entre o common law inglês e o civil law brasileiro (e.g., concepções sobre 'guarda'; poder familiar; arranjos de guarda; e o processo judicial em processos de guarda e convivência), as quais podem impactar o processo de tomada de decisão e os melhores interesses da criança.

\section{PALAVRAS-CHAVE}

Divórcio. Disputa de guarda. Guarda dos filhos. Civil law. Common law.

\section{INTRODUCTION}

Defining and evaluating 'the best interests of the child' principle (BIC) in a post parental separation scenario is a complex task for legal actors (judges, prosecutors ${ }^{1}$, psychologists, social workers and lawyers) working on cases in which the parents have separated and a decision regarding with whom a child is to live has to be made. Decision-making is complex because ensuring the BIC in child custody and access ${ }^{2}$ after parental separation involves moderators that can vary according to two main interdependent layers: (1) legal constraints; and (2) legal processes. The main constraint in such cases is the BIC principle itself (what it is; what encompasses it; how to evaluate it) and the scenario in which such decision will be made (child's idiosyncrasies; family crisis and development; legal actors' personal views on 'legal practice', 'divorce', 'family’ and 'child'). On the other hand,

1 Only in Brazil as English prosecutors do not act in such cases.

2 Within the English Law concerning private law cases, 'custody' is not referred to anymore. Since Families Act 2014, the correct term is 'child arrangement' and it addresses issues regarding the child after the breakdown of the parental relationship. Thus, 'custody' is used in this paper as a general and uniform term to designate, in both countries: $a$ ) where the children will live; $b$ ) how much time they will spend with each parent; and $c$ ) access to the child: arrangements for parents to visit/see their children after parental separation. 
the process is related to the legal system (civil or common law) and to the legal actors' evaluation of the BIC in each case (assessing; analysing).

This paper presents a narrative literature review that addresses these two layers through a comparison between Brazil and England. The main goals are: (1) to address contextual issues that can affect the decision-making process in child custody cases after divorce/parental separation ${ }^{3}$; (2) to underline how both countries legally frame BIC; (3) to compare legal processes regarding divorce/parental separation and child custody in both countries; and (4) to compare how Brazil and England process child custody cases after parental separation. To attain these goals, this paper will address developmental issues regarding parental separation. Then, the BIC origins and its general characteristics will be examined. In addition, legal processes of parental separation and child custody dispute will be addressed by highlighting legislation and case law in Brazil and England. Finally, conceptions regarding custodial arrangements, their characteristics and implications in both countries will be discussed.

\section{FAMILY LIFE CYCLE, DIVORCE AND CRISIS: (MIS)FITTING THE CHILD'S WELFARE}

The Family Life Cycle (FLC) is a model that encompasses the divorce as a phase in some families' developmental course. The way a family goes through this phase will shape the divorce outcomes that impact the family's and child's welfare, and how a family will cope. Usually, when the family cannot cope well, that is, they cannot understand and solve their own issues regarding the divorce, they go to the family court to seek for help - if the dispute becomes acrimonious, it can impair the BIC (MENDES; ORMEROD, preprint).

FLC is a normative developmental model created by McGoldrick, Preto and Carter (2014). The authors established some expected stages throughout the family developmental course. Each stage represents a crisis moment for the whole family because it requires changes, reorganisation and re-shaping within the family interactional dynamics and roles.

There are seven stages of family development: (1) leaving home - emerging as young adults; (2) the joining of families through marriage/union; (3) becoming families with young children; (4) being families with adolescents; (5) being families in midlife - launching children and moving on;

3 Despite legal and definitional differences, this paper considers 'divorce' and 'parental separation' as the same thing: the relationship breakdown. Thus, from here on, both will be referred only to parental separation, in which divorce is included. 
(6) families' late middle age; and (7) families nearing the end of life (MCGOLDRICK; PRETO; CARTER, 2014).

Those are expected stages that present specific challenges to the family experiencing them. But there are also unexpected stages that equally comprise FLC, that are, thus, part of the family development. One of these unexpected stages is divorce. It is an unexpected stage that deviates from an expected developmental course and destabilises the family system (like any other stage) due to changes, gains, and losses throughout the process of overcoming that stage.

The biggest challenge for the ex-couple is to put efforts towards accepting and adapting their changed interactional pattern and roles. During a divorce, the biggest challenge is to separate marital issues (e.g., frustrations, bitterness, disappointments, cheating, assets and financial issues) from parenting ones - e.g., affection, protection, upbringing, support, parental limits and looking after children in general (HAMEISTER; BARBOSA; WAGNER, 2015; JURAS; COSTA, 2017; PONCIANO; FÉRES-CARNEIRO, 2017). When marital issues overlap parental ones, escalating litigation is very likely at the point the family face a destructive divorce.

A destructive divorce occurs when the former couple engages in conflicting and highly litigious interactions and dysfunctional communication. This dynamic arises when the ex-couple is not able to overcome the relationship breakdown and keeps engaging in fights after the separation in an unconscious attempt to stay connected with one another. This phenomenon is recognised in the literature regarding divorce and child custody cases (ANTUNES; MAGALHÃES; FÉRESCARNEIRO, 2010; CANO et al., 2009; HASHEMI; HOMAYUNI, 2017; JURAS; COSTA, 2017; MENDES; BUCHER-MALUSCHKE, 2017; ROSMANINHO, 2010). Usually, it happens when the ex-couple, after formal separation, cannot go through a process of 'emotional digestion' and reorganisation of their lives, roles, identity and feelings regarding the ex-partner and the breakdown itself. Thus, they cannot have an 'emotional divorce' so they engage themselves in a destructive divorce.

When an ex-partner cannot emotionally divorce themselves from the other partner, it is likely that they may stay immersed in that relationship and its psychodynamic symbology for many years (ANTUNES; MAGALHÃES; FÉRES-CARNEIRO, 2010; MCGOLDRICK; PRETO; CARTER, 2014). In a child custody dispute, the 'emotionally undivorced parents' can be recognised as highly aggressive towards the other, disregarding interventions and/or reflections with inflexible and stubborn positions, and a communication framed by the 'adversarial game' (ANTUNES; MAGALHÃES; FÉRES-CARNEIRO, 2010). Those parents then unconsciously engage themselves in intractable disputes as a way to still be emotionally connected to the ex-partner (ANTUNES; 
MAGALHÃES; FÉRES-CARNEIRO, 2010). These are complex issues because they can lead the family cyclically to dysfunctional and unstable developmental transactions that, in turn, increase the chances of conflict, violence and disruptions (GREENE et al., 2012; MCGOLDRICK; SHIBUSAWA, 2012). This dynamic can lead, not just to intractable cases, but to 'endless cases' that present multiple or cyclical applications to the family court. This reveals an important layer of uncertainty in child custody cases: unconscious motivations. The authors suggest that neither parents nor legal actors are fully aware of this phenomenon.

This scenario can lead to expressions of violence (e.g., physical, psychological, verbal, financial) between the ex-couple, which can affect children (COSTA et al., 2009). The former couple cannot recognise their responsibilities in the conflict and both of them tend to lay blame and look for allies (JURAS; COSTA, 2017; MACIEL; MENDES; BARBOSA, 2021). Their first target for an alliance is often children, which can be 'triangulated' and/or 'parentified' in parental conflicts, as described below.

A child is triangulated when the stress, anxiety and anguish caused by the parental conflict reaches an unbearable level, leading the children to get involved in the conflict, to mediate it in an attempt to reduce the tension between the parents and within the family system (JURAS; COSTA, 2017; MENDES; BUCHER-MALUSCHKE, 2017). A common outcome of triangulation is to have the child allied to one of the parents and against the other. Hence, a high level of parental conflict tends to lead the child to pick one side. Triangulations and collusion dynamics are frequent in child custody cases. These dynamics are not always dysfunctional or even permanent, as they might be just a way the family has to navigate and adapt itself throughout transitional developmental stages, especially very stressful ones (EMERY, 2012; JURAS; COSTA, 2017; MENDES; BUCHERMALUSCHKE, 2017). In this sense, some triangulations can even benefit the family. The problem is when the dynamic of these triangulations loses its transitional and adaptive character and becomes a long-lasting transactional structure within the family, highlighting rigid oppositions that increase tension between the family members. This can lead to coalitions and inflexible loyalties that impede the family to keep its functional development (BARBOSA; MENDES; JURAS, 2021; BOWEN, 1991; JURAS; COSTA, 2017; MINUCHIN; COLAPINTO; MINUCHIN, 2006).

A child is parentified when they display behaviours that would be expected from parents. Usually, it happens when siblings have to look after each other because the parents are so involved in their conflict that they cannot properly parent their children.

Both triangulation and parentification dynamics can impair the child's interests and psychoemotional welfare (MENDES; BUCHER-MALUSCHKE, 2017). They can make parents blind to 
their child's needs and welfare, especially when they over-focus on the conflict and litigation, even using children to increase and keep the dispute going. The dynamics are associated with destructive divorce and are set as an attempt to avoid family breakdown and the next development phase, which is parental separation. Any stage in family development represents a crisis moment, not only due to all the changes that are going on, but also because family members may be afraid of changes that can lead to the family's end. In a divorce, this fear and the strategies used to cope with it can aggravate the situation, as there is a sense that divorce means the end of the family. That's why some families go through a destructive divorce. By means of litigation and successive disputes in the court, the excouple, usually unconsciously, keep their bond and avoid moving on (ANTUNES; MAGALHÃES; FÉRES-CARNEIRO, 2010; HASHEMI; HOMAYUNI, 2017; JURAS; COSTA, 2017; MENDES; BUCHER-MALUSCHKE, 2017; ROSMANINHO, 2010).

As seen, the FLC and all the developmental issues involved in a parental separation can portray a scenario of confusion and disorganisation for the family that struggles to cope with all the changes and implications arising. They usually do so by means of non-assertive and dysfunctional strategies that encompass the crisis moment presented by the parental separation (BARBOSA; MENDES; JURAS, 2021). It is important that legal actors, especially judges and prosecutors, are aware of those issues, as it is known that families going through parental separation and child custody dispute seek judicial aid when they are facing a crisis moment (MOSTEN; TRAUM, 2017). The family lifecycle raises important contextual issues that bring significant uncertainty to the decisionmaking process. Depending on the way legal actors manage them, that process can be more or less difficult.

\section{THE BEST INTERESTS OF THE CHILD}

The BIC principle is a tool commonly used to measure and weigh outcomes in any legal situation concerning children. To better understand BIC, one has to consider its evolution from its historical background to its current approach, as follows.

\subsection{HISTORICAL BACKGROUND}

The current concepts of 'child' and 'childhood' originated three centuries ago when childhood began to be seen as a different stage of development, carrying special needs that differ 
from adulthood (ARIÈS, 1982) ${ }^{4}$. This differentiation emerged through (MENDES; LORDELLO; ORMEROD, 2020, p. 55-58): I) the arising of 'child' and 'childhood' as meaningful socio-cultural constructs: II) the development of custody decision-making paradigms; and III) the development of international law advocating on behalf of child's rights and well-being ${ }^{5}$.

The notions of 'child' and 'childhood' are social constructions that are determined by the cultural approach of each historical period and society ${ }^{6}$. Until the $17^{\text {th }}$ century, the child was seen as 'little adult' with no specific social role or identity, but just as a 'replaceable object'. By the age of seven years old, children used to be inserted into the 'adult life', mimetically reproducing adults' habits, tasks and roles (ARIÈS, 1982). Medieval art did not represent children properly, only in sacred paintings and usually portrayed with an 'adult figure', which reinforces the idea that there was no socio-cultural place for children at that time, leading to marginalisation, discrimination and exploitation (ARIÈS, 1982). As a consequence, during the Middle Ages, rates of infanticide and child mortality were high - between 30\% and 50\% (FERRARO, 2013).

Other factors also contributed to the arising of the contemporary conceptions of 'child' and 'childhood', such as the Enlightenment, Liberalism and Industrial Revolution (WOLFF, 2013; WURTZ, 2020) ${ }^{7}$. The influence of the Church and the State also played a role and led to changes within society and its culture, as well as its values and habits. Ariès (1982) suggests that society commenced to look differently at the children, and provision of love and caring for them started to be part of social expectations towards the family. However, some historians dispute that and believe that parents were always attached to their babies and treasured them (FERRARO, 2013). Later, conceptions of 'child' and 'childhood' improved, and children's well-being became a matter of interest and action of the State. The 18th-century hygienist movement also contributed with policies aimed at educating and shaping the family to be the main source of protection, affection and care for children - germinal issues for the current hegemonic 'nuclear family’ model.

4 The majority of Ariès' assertions was based on his thorough analysis of medieval paintings, literature, philosophy, religious believes and letters from that period. Some critics argue that Ariès' assertions might have been done in a 'over generalisation' fashion. Despite that, his work and findings are recognised worldwide (and especially in Brazil) as milestone for the study of 'childhood' across various disciplines.

5 For further discussions regarding 'childhood' in the classical antiquity, please see BRADLEY (2013).

6 A social construction concerns the process in which conceptions, definitions, roles and functions of things are mutually constructed throughout social interactions across cultures, societies and certain periods of time. For more discussions regarding 'childhood' as a social construction, please see NOROZI; MOEN (2016).

7 Some authors (ALLANEN, 2001; MOURITSEN, 2002) also believe that, under a Marxist view, the emergence of 'childhood' was a bourgeois strategy created to ensure the provision of a well-educated and domesticated work-force. This also would have engendered the notion of 'nuclear family' (RÖDER, 2018). 
This scenario enabled the emergence of the 'best interest of the child' principle, although its seed was lodged some centuries before by the parens patriae $e^{8}$ doctrine that was prominent in the $13^{\text {th }}$ century when the English crown claimed wardship over the so-called 'lunatics' and 'idiots' (CUSTER, 1978; MENDES; LORDELLO; ORMEROD, 2020). The rationale behind that doctrine was that the king would be the 'father of the nation', therefore a parens patriae, that would have the power to protect and act on behalf of the weak and powerless. Later, between the $17^{\text {th }}$ and $18^{\text {th }}$ centuries, this doctrine started to be applied in cases involving children, especially when the English Courts of Chancery was judging a child custody case. During the $19^{\text {th }}$ century, English law used to solve a custody dispute by placing the child with the father (MENDES; LORDELLO; ORMEROD, 2020). The same happened in America, where the child had economic importance for the household, notably the father. This practice was based on the ancient Roman rule regarding the 'paterfamilias', which was a single man with powers to control all the domestic and public life of women, children and slaves (LEHR-LEHNARDT; GUNN, 2011). Therefore, the child was seen as a father's property. This idea changed by the end of the $19^{\text {th }}$ century and the beginning of the $20^{\text {th }}$ as the Courts started to consider which parent would better fit the child's needs (SWARTZ, 2017). This was the first time that a child's interests were underlined and seen apart from their parents'. Nevertheless, the law continued to consider women and children to be inferior.

In the first part of the $20^{\text {th }}$ century, the custody paradigm shifted more than once in the (MENDES; LORDELLO; ORMEROD, 2020). Initially, there was the 'fault-based rule' in which the innocent party in the divorce would be awarded the guardianship. During this period, divorce was usually requested by women, so they were required to prove that the divorce was not their fault to in order to have the child's custody (NATHAN, 2015). This dynamic led judges to award custody to mothers more often, shifting the custody paradigm to 'maternal primacy'. Later, the family courts established the so-called 'tender years' doctrine that presumed the mother, just for being woman and mother, would fit better the child's needs and care, especially new-borns and children under three years old. This doctrine was enacted as statutes and common law among family law in the United States of America, England and within family courts around the world (NATHAN, 2015).

The 'tender years' doctrine started to be criticised by the feminist movement in the 1960s and later by the 'fathers' rights' movement between 1970 and 1980 (MEYER; CANCIAN; COOK, 2017). They pleaded for a neutral-gender custody decision-making paradigm ${ }^{9}$. Following this

8 Parens patriae originated within the Roman Law. For further discussion, please see MCGILLIVRAY (2016).

9 However, some judges might still be influenced by this doctrine - see ARTIS (2004). 
movement, the 'best interests of the child' principle, advocated by the United Nations Convention on the Rights of the Child in 1989, became a more neutral-gender paradigm that lasts to this day.

\subsection{CURRENT STATUS}

The 'best interests of the child' principle is encapsulated by the $3^{\text {rd }}$ article of United Nation Convention on the Rights of the Child (UNCRC), which broadly shelters all rights within the UNCRC itself. This article states that "in all actions concerning children, whether undertaken by public or private social welfare institutions, courts of law, administrative authorities or legislative bodies, the best interests of the child shall be a primary consideration”. However, neither the article nor the rest of the UNCRC offers any further definition of the BIC, its application nor the factors for evaluation, which is the main target for the BIC critics.

The United Kingdom (UK) and Brazil are both signatories to the UNCRC. In the UK, the BIC is mostly represented by the Children Act 1989 (UNITED KINGDOM, 1989) which clearly refers to the UNCRC $3^{\text {rd }}$ article in its first sections and items:

1(1) when a court determines any question with respect to- (a) the upbringing of a child; or (b) the administration of a child's property or the application of any income arising from it, the child's welfare shall be the court's paramount consideration. (2) In any proceedings in which any question with respect to the upbringing of a child arises, the court shall have regard to the general principle that any delay in determining the question is likely to prejudice the welfare of the child.

The Children Act 1989 (UNITED KINGDOM, 1989) also has a so-called 'welfare checklist' which the court is required to take into account. This includes, for example, the child's wishes, biopsychosocial needs, age and degree of understanding and physical safety - this check-list will be discussed later. In England, the 'welfare checklist' is the main source used to understand and evaluate the best interests of the child in child custody cases - this is discussed further in section 3.1.2.

In Brazil, the BIC is expressed on the $227^{\text {th }}$ article of its Constitution (BRASIL, 1988, our translation):

It is the duty of the family, the society and the State to ensure the child's right to life, health, food, education, leisure, professionalization, culture, dignity, respect, freedom, family coexistence and community life, and to safeguard them from all forms of neglect, discrimination, exploitation, violence, cruelty and oppression.

Following the UNCRC, Brazil also enacted the Child and Adolescent Statute, establishing, defining and providing representatives for children and adolescents’ rights. 
Mendes and Ormerod (2019) conducted a systematic review of the best interests of the child in Portuguese and English literatures. The authors found that the literature understands that to promote the BIC one has to: (1) protect the child's physical and mental welfare; (2) provide basic children's rights: (3) preserve the child's physical and non-physical interests and needs (both materialphysiological and contextual - e.g., affection); (4) to understand the BIC essential idiosyncratic nature (varies case to case); (5) to consider the child as a subject of rights; (6) to take into account the child's relational context (family, school, community); (7) understand that BIC is multidimensional; and (8) contextualise and trade-off interests and needs.

\section{DIVORCE AND LAW: THE BRAZILIAN CIVIL LAW AND ENGLISH COMMON LAW SYSTEMS}

Legal systems' characteristics and their legislation shape the way legal actors work through assumptions and conceptions. Civil and common law systems have different ways to address divorce and child custody throughout their legal tradition and proceedings. These differences can affect how the family, the children and their best interests will be seen and managed within family courts and the decision-making process.

There are three types of legal systems: 1) civil law; 2) common law; and 3) socialist law. These systems carry specific legal traditions that locate each of them in a cultural perspective (CRUZ, 2007). Brazil adopts the civil law system and England has the common law system. To classify and understand differences between those systems, Zweigert and Kötz (1998) proposed some juristicstyle criteria, such as viewing the system's: $a$ ) historical background and development; $b$ ) emblematic mode of thought; $c$ ) typical institutions; $d$ ) types of legal source (and how it treats them); and $e$ ) ideology.

The English common law system is based on "unwritten customary law evolved and developed throughout the centuries with pragmatism, strong monarchs, an unwritten constitution and centralised courts being its typical features” (CRUZ, 2007, p. 38). In this sense, some classical definitions tend to assert that common law does not have a legislative tradition as it was developed in and by courts highlighting the judges’ role in making laws ${ }^{10}$. Common law works in a concrete, courtbased way that looks for pragmatic answers when problems are presented before the court, according

10 Some authors and legal practitioners dispute that assertion by acknowledging that, within the common law, quite often some statutes (written law) tend to amend, adjust and refine the customary law - see POJANOWSKI (2015). 
to a 'case-to-case' procedure and, in this system, the main source of law tends to be case law or judicial precedent ${ }^{11}$.

The civil law system is also known as 'Roman-Germanic' because its historical background reflects Roman and Germanic law origins. Due to its inheritance, civil law contrasts with common law by presenting substantive law principles. Civil law was "formulated, compiled and refined in the universities, later codified and then given statutory force by the legislature” (CRUZ, 2007, p. 38). It tends to be more abstract, conceptual and symmetrical, being governed by specific rules that try to foresee and solve problems before they reach the court and it is operated by a 'principle to principle' procedure. In this system, the main source of law is codified or enacted law.

The differences between those two systems impact the way legal actors within each of them understands and operate the law, especially in child custody and access cases after parental separation. Both systems address public law and private law in the same way, the latter regarding relations between private citizens and organisations, the former referring to disputes involving the State as a party. In Brazil and England, divorce is a private law matter. However, in Brazil, there are some cases in which the State is seen as an interested (and public) party and non-criminal prosecutors can be involved - this will be explained later on.

Apart from the formal ways to constitute lawful adult relationships (religious and/or civil marriage), Brazilian legislation can also legally bind what is called 'stable union' (equivalent to 'common-law marriage'12), an informal union between two persons that resembles a matrimonial bond. There are some requirements to set a ‘stable union’ (GONÇALVES, 2017): (a) subjective: i) more uxorio ${ }^{13}$ relationship: two persons sharing their lives, cohabitating (or not) with "mutual material, moral and spiritual assistances, exchange and the sum of 'living together' interests, affection; in short, the sum of material and spiritual components that underpin the affective relations inherent to the family entity (GONÇALVES, 2017, p. 800)”, ii) affectio maritalis: 'marital affect' that refers to the will and purpose to constitute a family with the other person; $(b)$ objective: $i$ ) notoriety: must be under public acknowledgement, cannot be a secret relationship, ii) stability or longterm involvement, iii) continuity: the relationship cannot be intermittent, iv) no matrimonial

11 In the history of the common law, there were few statutes and much of law was being developed by judges in decisions in specific cases. But that is almost certainly no longer true of the common law tradition in England. Nowadays, there are complex statutes with which judges interact in their case-by-case decision-making.

12 The English Law does not secure to ‘cohabiting couples' rights that a legally married couple. In this sense, unmarried partners do not have enhanced rights regarding assets, properties etc. - see REECE (2015).

13 Expression inherited from Italian law that designates the condition of two people living together without being officially married. 
impediments: both persons must be single, divorced or widow/widower and not relatives ${ }^{14}$, and $v$ ) monogamous relationship ${ }^{15}$. In sum, within Brazilian legislation, 'stable union' has analogous rights and duties, when compared to a civil marriage, especially regarding the children. After being recognised by a court, a stable union can have analogous protections likewise a formal marriage.

In Brazil, marriage and divorce are both ruled by the Brazilian Constitution and Civil Code. There are three types of divorce: $a$ ) consensual extrajudicial divorce: possible only when there are no children under 18 years old (or a mentally incapable person) and/or any other matter (e.g., goods and assets) that requires judicial involvement - in this case, a public notary recognises and certifies the divorce; $b$ ) consensual judicial divorce: when the ex-couple agrees upon all the relevant matters (e.g., residence and contact with the children, child maintenance, goods, assets, etc.) and then make an application so the court can analyse and recognise the agreement and certify the divorce and its terms; c) litigating judicial divorce: when the ex-couple cannot agree upon all the relevant matters (e.g., residence and contact with the children, child maintenance, goods, assets, etc.) and then make an application so the court can analyse the whole case and make decisions regarding those matters and then certify the divorce and its terms.

In the English Law, divorce is mainly ruled by the Matrimonial Causes Act 1973 (MCA, 1973) and Family Procedure Rules 2010. In England, there is no extrajudicial divorce, so marital separation has to go through an application at a divorce court. The marriage dissolution will be granted only if there is 'irretrievable breakdown', based on at least one of five factors: adultery; respondent behaviour; desertion; two years separation (with consent); and five years of factual separation (HERRING, 2019b).

In both countries, even after several reforms, the institute of judicial separation is still possible. This process ends the conjugal union but not the marriage. In Brazil, judicial separation used to be a fault-based procedure that could be issued for one of the spouses in an attempt to punish the other for breaking the marital obligations. After Constitutional Amendment 66/2010, that procedure was overruled. In England, this type of separation is issued whenever one of the spouses objects to the divorce due to religious beliefs, when the marriage has not completed one year (as divorce can be granted only after one year of the marriage). However, in both countries, it has become a less frequent procedure and whenever invoked it must be justified before the court. Either way, this type of

\footnotetext{
14 If the person still is officially married but do not live together and/or do not share a 'couple life' with their former partner anymore, they could have a 'stable union' with a new partner.

15 However, there are some legal opinions and jurisdictions that do not require monogamy as a factor to grant a 'stable union'.
} 
separation can increase parental litigation and, therefore, typically harms the BIC and hampers the decision-making process.

In any judicial parental separation, Brazilian prosecutors ${ }^{16}$ can take part in the evaluation and decision-making process, highlighting the State's interests and roles as well as the observance of the law. A Brazilian prosecutor only takes part in such cases that involve children who are considered 'incapable'17. Hence, children would have what Brazilian civil law calls 'unavailable rights'. These refer to rights that, due to their specific nature, do not allow the person to relinquish them because they are irrevocable, inalienable and non-transferable such as the right to life, health and dignity (VENTURI, 2016). These rights are 'unavailable' because the person cannot dispose of them in any type of transaction and/or agreement. They are, then, non-negotiable rights and, therefore, must be protected, especially by the State. Thus, in post parental separation disputes involving issues regarding children, prosecutors would act on behalf of the best interests of the child. This is according to the Article $227^{\circ}$ of the Brazilian Constitution and also the Child and Adolescent Statute.

Chart 1 presents a summary of both systems' characteristics and how each of them approaches divorce:

16 They are, likewise, English Crown Prosecutors. However, their performance and duties go beyond criminal matters and safeguards child's rights, environmental protection, protection of minorities' rights and so on. Thus, in noncriminal cases, their role is to evaluate how people's rights and the State's interests (as expressed in the Constitution) are being taking into account or not. In general, the role of prosecutors in Brazil is to act as a custos legis ('guardian of the law') by making sure that people’s rights and the law itself is not being jeopardised. For further discussions regarding the general role of Brazilian prosecutors, please see MUELLER (2009, p. 106-107).

17 Meaning: due to their developmental stage, they are incapable to dispute and ensure their own interests, so prosecutors would be their best interests guardians. 
Chart 1 - Brazilian and English legal systems and their approach to divorce

\begin{tabular}{|c|c|}
\hline \multicolumn{2}{|c|}{ Legal system characteristics } \\
\hline Brazilian civil law system & $\begin{array}{r}\text { English common law system } \\
\end{array}$ \\
\hline $\begin{array}{ll}- & \text { substantive law principles } \\
- & \text { abstract and conceptual } \\
- & \text { written constitution } \\
- & \text { codified rules (through legislation) } \\
- & \text { principle-driven }\end{array}$ & $\begin{array}{ll}- & \text { unwritten customary law } \\
- & \text { pragmatic } \\
- & \text { unwritten Constitution } \\
- & \text { no legislative tradition } \rightarrow \text { court-based } \\
- & \text { 'case-to-case' driven } \\
\end{array}$ \\
\hline \multicolumn{2}{|c|}{ Addressing divorce } \\
\hline $\begin{array}{c}\text { Brazilian civil law system } \\
\end{array}$ & English common law system \\
\hline 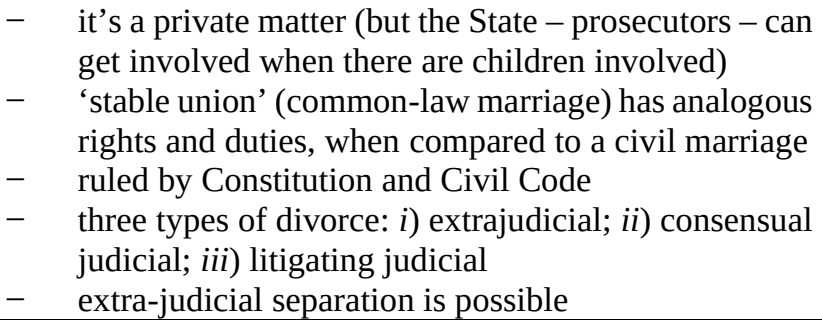 & $\begin{array}{ll}- & \text { it’s a private matter } \\
- & \text { ruled by Matrimonial Causes Act } 1973 \\
- & \text { only judicial divorce } \\
- & \begin{array}{l}\text { divorce is granted based on an 'irretrievable } \\
\text { breakdown' principle }\end{array}\end{array}$ \\
\hline
\end{tabular}

Source: the authors, 2021.

\subsection{BRAZILIAN AND ENGLISH LEGAL APPROACH TO DIVORCE AND CHILDREN'S WELFARE}

Both countries have different ways to legally address the marital relationship breakdown and the child's welfare. These differences are also cultural and have been absorbed by the legislation. This section will present key-concepts, proceedings and possibilities of custodial arrangement after parental separation.

\subsubsection{Basic concepts and proceedings}

Before addressing how each country approaches children’s welfare after parental separation, it is important to discuss how each of them sees and understands the child's residence and contact issues whenever the separated parents cannot reach a settlement. In Brazil, when there is a judicial parental separation that involves children, one of the decisions to be made is to define and then award what in Brazil is called as the child's 'guarda'. The standard translation for guarda would be 'custody', but its meaning is closer to 'guardianship'. Guarda is an arrangement that considers with whom and where the child will live as well as how the non-custodial parent will have contact with the child. Applications for guarda can be made until the child is 18 years old. In England, all the matters regarding who a child is to live, and the contacts with the non-custodial/residential parent (direct or indirect), are dealt with as ‘child arrangements orders' (CAO). A CAO application can be 
made until the child is 16 years old and exceptionally until they are 18 years old - all CAO are regulated by Section 8 of Children Act 1989.

The current English legislation regarding children in private and public laws has abolished the word 'custody' and started to use 'child arrangements' to designate a court order concerning “(a) with whom a child is to live, spend time or otherwise have contact, and (b) when a child is to live, spend time or otherwise have contact with any person” (Section 8(1), Children Act 1989). More than that, the legislation has abolished the 'custody' concept regarding a child, meaning that this change was not a mere substitution. The aim of the legislator was to clarify and set that the child is not an object to be under custody.

'Child arrangements' is a generic term that leads the courts to evaluate each case and set orders according to the child's and family's idiosyncratic characteristics. That is a significant contrast between Brazilian and English systems, as Brazil not only refer to guarda (meaning custody) but also only offers two types of custodial arrangement: sole custody and joint custody (with or without shared care). Moreover, the latter is a default-arrangement bound by the law that should be applied to every and each case, especially in those in which parents cannot reach an agreement. Therefore, in theory, sole custody would be awarded only when and if one of the parents does not show interest in the custody. Stating a default decision for child custody after parental separation can potentially hamper the decision-making and is a very controversial issue that won't be addressed in this paper as it is not its goal ${ }^{18}$.

Another interesting difference between Brazil and England is how they understand the continuity of the relationship between the child and the non-custodial parent after parental separation, in other words: the child's right to maintain their emotional bond with both parents. In England, it is referred to as 'access' or 'keeping the contact', meaning the child has the right to keep in touch with the parent that does not live with them. On the other hand, in Brazil, it is referred to as 'convivência' (meaning 'coexistence'), that is, the child has the right to keep sharing a life (i.e., their existence) with the non-custodial/residential parent.

In Brazil, the payment of child maintenance is referred to as alimentos (close to the North American notion of 'alimony') and can only be legally enforced by going to the court so both judge and prosecutor can testify that the arrangement is on behalf of the child's interests. The calculation regarding how much maintenance shall be paid is not fixed and can vary from case to case, according to the court's judgment - however, it is based in a threefold principle: (1) necessity (the child's

18 In England, some authors and legal practitioners understand that Section 1(2A) of the Children Act 1989 indicates a presumption of shared parenting - see KAGANAS (2018). 
specific needs); (2) possibility (the financial possibilities of the other parent); (3) proportionality (a fair amount according to the parent's income) (ROSA, 2015). Depending on how the solicitor applies to the court, guarda and child maintenance can be judged at the same time, which can have the adverse effect of prolonging litigation and harming the child's best interests. In its Art. 5º item LXVII, the Brazilian Constitution (BRASIL, 1988) enacts the possibility of incarceration for parents that do not pay the child maintenance. Other codes have enforced it to the point that, in Brazil, it is common sense that not paying it will definitely lead to prison.

In England, separated parents are strongly encouraged to set the child maintenance by themselves, which is called 'family-based agreement'. In this case, there is no official involvement or legal approval, and the information and support to set up that agreement is provided by the Child Maintenance Options (HERRING, 2019b). If this initial attempt fails, the 'parent with care' ${ }^{\text {19 }}$ can apply to the Child Maintenance Service (CMS). This agency will try to sort out any issues and/or disagreements that are impeding the child maintenance to be settle - to access these services' assistance, parents have to pay a fee (victims of domestic violence and under 19 years old parents are exempt). These two services have a general formula to calculate how much maintenance shall be paid. If the non-custodial/residential parent’s weekly income is between $£ 200$ and $£ 800$, the amount to be paid is as following: $12 \%$ of gross income for one child; $16 \%$ of gross income for two children; $19 \%$ of gross income for three or more children. If the weekly income is higher than $£ 800$ : $9 \%$ of gross income for one child; $12 \%$ of gross income for two children; $15 \%$ of gross income for three or more children (HERRING, 2019b). In some rare cases, parents can apply for a court 'consent order' to top up the maintenance ${ }^{20}$. In England, child custody and child maintenance are seen and decided as separated matters.

In Brazil, child maintenance obligations last until the child reaches 18 years old and 21 years if they are in a full-time training or educational course up to A level or equivalent - however, some jurisdictions do not require a full-time A level course and the Brazilian Supreme Court has decided, recently, that maintenance shall last until the person graduates or completes 24 years old. In England, these obligations last until the child is 16 or 20 years old if they are in full-time education (HERRING, 2019a).

When addressing the legal binding of the relationship between parents and children, English law refers to 'responsibility' and Brazilian law to 'power'. That is another interesting contrast that

19 It is the parent that is responsible for the ‘day-to-day care’ (HERRING, 2019b).

20 For further information regarding Child Maintenance in England, please consult the Child Maintenance and Other Payments 2008; the reader can also check the work of Skinner (2012). 
underlies the views each legal system has regarding children, parents, families and the relationships between them. The Children Act 1989 (UNITED KINGDOM, 1989) stated in Section 3(1) that “"parental responsibility”” means all the rights, duties, powers, responsibilities and authority which by law a parent of a child has in relation to the child and his property”. Brazil has an equivalent disposition in its Civil Code’s Article 1,634 which states that poder familiar (family power) consists in: $I$ - being responsible for their children's upbringing and education; $I I$ - parents have the right to have the sole or joint custody; III - parents can allow, or not, their children, when underage, to marry; $I V$ - parents have the right to consent to, or withhold consent for, trips outside of the country; $V$ parents have the right to consent, or withhold consent for, their children's relocation; [...] VII parents can act as a child's legal representative until they reach 16 years old; VIII - parents have the right to reclaim their children from those who hold them illegally; $I X$ - parents have the power to require their child to provide obedience, respect and domestic activities that are compatible with their age and condition.

These different characteristics and policies highlight an important contrast between Brazil and England in child custody matters. The English system tends to discourage legal disputes and altercations between the parents by stimulating self-composition ${ }^{21}$ and non-judicialisation of the family's conflicts. Although the Brazilian New Code of Civil Proceedings created specific routes to promote mediation and consensual settlement within Family Law, the reality is that the Brazilian system tends to stimulate judicial litigation - this will be further discussed in section 4 . That happens not only due to the judiciary's litigation mindset but also by the creation of legislation that not only judicializes the family's private life but also that fails to comprehend the interrelations within a family and, thus, tends to increase family litigation and incomprehension - e.g., the Parental Alienation Act (BARBOSA; MENDES; JURAS, 2021; MACIEL; MENDES; BARBOSA, 2021; MENDES, 2019; MENDES; BUCHER-MALUSCHKE，2017; MENDES; LORDELLO; ORMEROD， 2020; MENDES; ORMEROD, preprint). Also, in Brazil, child maintenance disagreements or failure in paying it usually impairs custodial arrangements and especially contacts between the child and the non-custodial/resident parent (MENDES; ORMEROD, preprint). This dynamic also seen in England (SKINNER, 2002). However, it tends to be less frequent in England due to the separation of child custody and child maintenance and the non-litigating nature of child maintenance in England.

21 This is related to processes in which both parties (parents) find a functional way to communicate their differences, interests and goals regarding the matter under dispute and to thereby reach an agreement by themselves, without judicial mediation. 
Chart 2 presents a summary of both legal systems' approach to parental separation and the children's welfare:

Chart 2 - Brazilian and English legal systems and their approach to divorce and the children's welfare

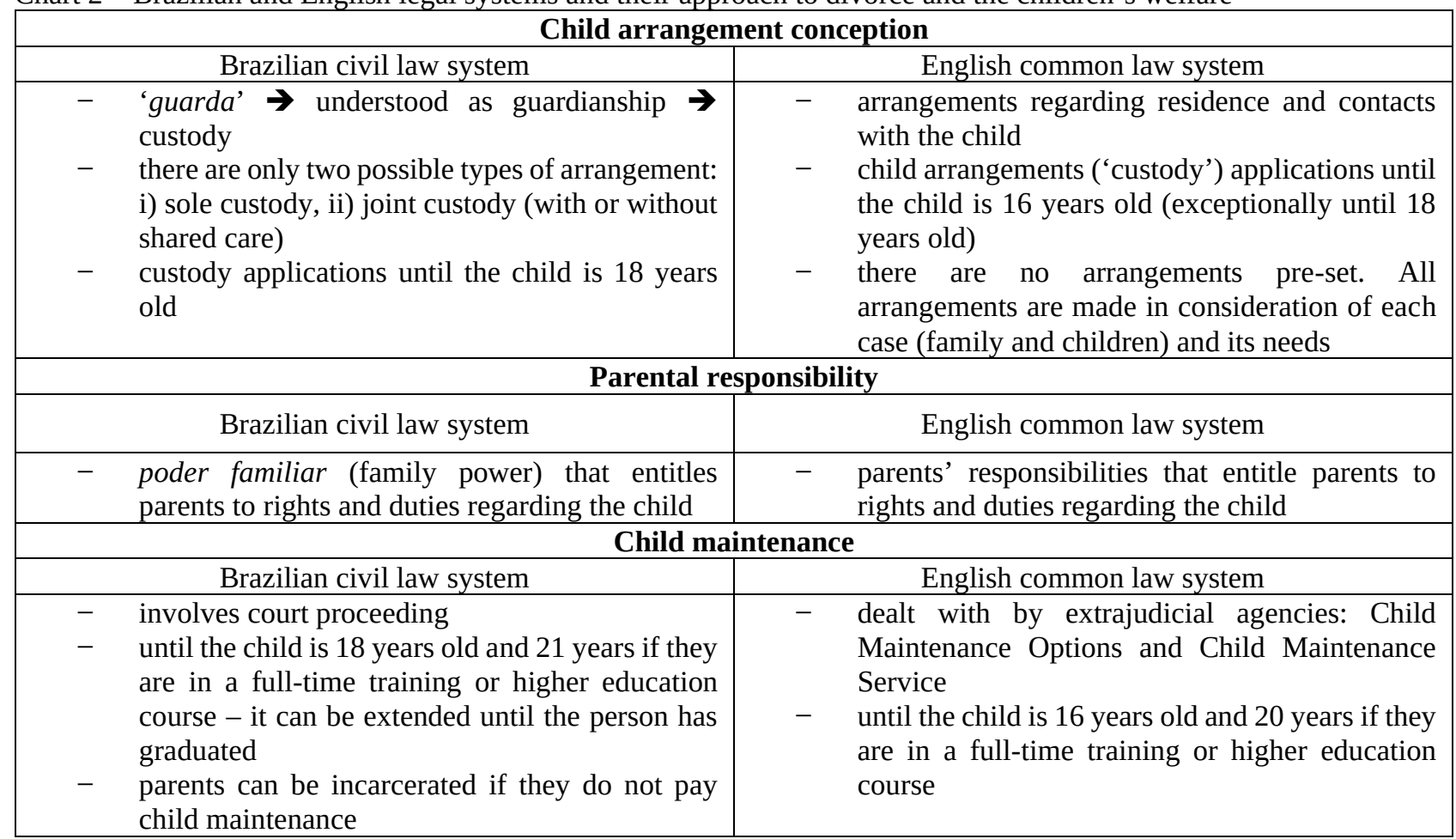

Source: the authors, 2021.

\subsubsection{The law regarding child custodial arrangements after parental separation}

The Brazilian Civil Code (BRASIL, 2002) has a specific chapter in its Family Law Book named 'Protecting the Offspring'. It is aimed to ensure that children will be protected after parental separation. The first article of this chapter, says that:

Art. 1,583. The guarda shall be sole custody or joint custody.

$\S 1^{\circ}$ Sole custody is a guardianship awarded to just one of the parents or someone else that replaces them, and joint custody is shared responsibility, rights and duties towards the family power that both father and mother, that do not cohabitate, have regarding their children.

$\S 2^{\circ}$ Regarding joint custody, contacts with the child must be divided in a balanced way between the mother and the father, taking into account factual conditions and the child's interests.

$\S 3^{\circ}$ Under joint custody, the city in which the child will reside shall be the one that best fits the interests of the children (BRASIL, 2002, our translation, our emphasis [italics]).

The second article provides guidance for application, contact with the child, and guidance to parents regarding joint custody:

Art. 1,584. The sole or joint custody will be: 
I - required by the father and the mother, consensually, or singularly by either of them, in an application for separation, divorce, dissolution of a stable union, or as a precautionary measure;

II - decreed by the judge, according to the child's specific needs, or due to the need to balance the child's contact with the father and mother.

$\S 1^{\circ}$ During the conciliation hearing, the judge will explain joint custody, its importance, the respective duties and rights of both parents and the penalties for noncompliance with its terms.

$\S 2^{\circ}$ When there is no agreement between the mother and the father regarding the custody of the child, and both parents are able to exercise the family power, joint custody shall be applied, unless one of the parents declares to the court that they do not wish be awarded child custody (BRASIL, 2002, our translation).

With the enactment of Act 13,058/2014 (BRASIL, 2014) that altered Art. 1,584, § $2^{\circ}$, joint custody became 'compulsory' to every case in which the parents cannot reach an agreement, unless one of the parents does not want custody. Hence, the joint custody should be awarded regardless of the parental conflict level portrayed. This alteration was due to jurisprudence from superior courts that understood

the focus is on the best interest of the minor, which is the driven-principle of the relationship between parents and children. It does not make sense to understand that joint custody is impossible when parents cannot reach a consensus. [...] Hence the assumption that joint custody impairs this principle is questionable, as this perception only highlights the parental conflict, ignoring the best interest of the child. [...] The end of conflicts between the former couple is not the aim, but rather the overcoming of obstacles that prevent joint custody to be set $^{22}$ (BRASIL, 2014, our translation, our emphasis).

This judgment, also, seems unconcerned with the child's interests, as it clearly states that the most important thing is to secure joint custody, regardless of any other issue. In other words, the main concern is with the arrangement and how it secures both parents' rights to have the child's companionship. Another issue with the Brazilian joint custody model is its obsession with time, meaning contact. It is referred to three times (Art. 1,583 § 2; Art. 1,584, II, § 3) always alluding to “a balanced division of time”, implying that the quantity of time overlaps with its quality.

Joint custody was possible within Brazilian Family Law before that alteration. In 2008, Act 11,698 already pointed towards joint custody as a possible arrangement. But why was Act 13,058/2014 enacted? There were debates arguing that, even though it was a possible arrangement, it was rarely awarded and, thus, non-custodial/residential parents had their rights and family power impaired. What is interesting is that $\S 5^{\circ}$ from Art. 1,583, Art. 1,589 and Art. 1,632 (BRASIL, 2002) make very clear that separated parents do not lose their rights and duties towards their children:

Art. $1,583 \S 5^{\circ}$ In the case of a sole custody arrangement, the non-custodial parent is obligated to supervise the interests of the offspring, and to enable such supervision, any

22 Brazilian Superior Court of Justice. Special Appeal no 1,251,000 - MG (2011/0084897-5). Judge-Rapporteur: Nancy Andrighi. Judged on: Aug. 23, 2011. Available from: https://bit.ly/3nbDogh [Accessed: 14 Apr. 2021]. 
parent will always be a legitimate party to require information and/or accountability, objective or subjective, in matters or situations that directly or indirectly affect the children's physical and psychological welfare and education.

Art. 1,589 The non-custodial father or mother may visit their children and have them in their company, according to the agreement with the other parent, or to the settlement fixed by the judge, and have the right to supervise their children's maintenance and education. Art. 1,632 Judicial separation, divorce, and the dissolution of a stable union do not alter the relationship between parents and children, but rather the right the parents have to have their children in their company (BRASIL, 2002, our translation, our emphasis).

$\S 3^{\circ}$ from Art. 1,584 highlights the role of prosecutors and, more importantly, the role of psychosocial staff to help the decision-making process:

$\S 3^{\circ}$ In order to establish the attributions of the father and the mother and the periods of contact under joint custody, the judge, ex officio ${ }^{23}$ or at the request of the Public Prosecutor's Office, may be based on professional or interdisciplinary team's orientation, which should aim at the balanced division of time between father and mother (BRASIL, 2002, our translation, our emphasis [italics]).

In England, the disputes over a child’s upbringing are ruled by Children Act 1989, Children and Adoption Act 2006 and amendments from the Children and Families Act 2014. A child arrangement order is what parents are seeking in a child custody case. This order is instructed by the Children Act 1989's Section 8, which determines who and where the child should live with and how much time the child will have with each parent. Although this order can apply until the child is 18 years old, the court will rarely institute an order when the child is over 16 years old; only in exceptional circumstances (HERRING, 2019a). Before the Children and Families Act in 2014, child arrangement orders were referred to as either 'residence' or 'contact' orders. Now there is just a 'child arrangement order'. It is important to highlight that, in contrast with Brazilian law, English law does not specify and/or limit the type of custodial arrangement that should be set or even specific mentions to 'time balance', like in Brazil. The English law makes very clear that orders concerning child arrangements can be framed by detail and conditions.

Whenever judging a child arrangement case, English courts primarily apply the welfare checklist illustrated at Section 1(3) of the Children Act 1989, which displays the following factors (UNITED KINGDOM, 1989): (a) the ascertainable wishes and feelings of the child concerned (considered in the light of his/her age and understanding); (b) his/her physical, emotional and educational needs; $(c)$ the likely effect on him/her of any change in his circumstances; $(d)$ his/her age, sex, background and any characteristics of his which the court considers relevant; $(e)$ any harm which he/she has suffered or is at risk of suffering; ( $f$ ) how capable each of his/her parents, and any other

23 Latin expression that means for duty of office, for obligation and regiment. It is said of the official act that takes place without an application from the parties. In sum, it refers to prerogatives that the judge has for being a magistrate. 
person in relation to whom the court considers the question to be relevant, are of meeting his/her needs; and $(g)$ the range of powers available to the court under this Act in the proceedings in question. Another tool the court has is to nominate a guardian ad litem, who will represent the child's interests before the court - so the child will be part in the case alongside their parents. This guardian is usually employed in very complicated and intractable cases and they are appointed to children in circumstances in which the court thinks that the interests of parents and children diverge (to represent the interests of children to the court). Their role is to talk to the child in order to gather their wishes, feelings and welfare interests in general and then report them to the court, but always weighing what is best for the child. Sometimes, the guardian can also appoint a solicitor to represent the child in the case - if the child is 'Gillick competent' ${ }^{24}$, they can ask for a lawyer by themselves.

The enactment of the Children and Families Act 2014 (UNITED KINGDOM, 2014) was also meant to foster less hostile parental disputes over a child's upbringing (HERRING, 2019a). One of the actions with this purpose is in Section 10(1), which states that "before making a relevant family application, a person must attend a family mediation information and assessment meeting”. In Section 11, CFA 2014 stated that the involvement of both parents in the child's upbringing would be fundamental, unless the contrary is shown. In contrast with Brazilian law, when it addresses joint custody, CFA 2014 says that involvement "means involvement of some kind, either direct or indirect, but not any particular division of a child's time” (UNITED KINGDOM, 2014).

Chart 3 presents a summary of both legal systems’ approach parental separation and child arrangements:

Chart 3 - The law regarding child arrangements after parental separation in Brazil and England

\begin{tabular}{|c|c|}
\hline Brazilian civil law system & English common law system \\
\hline $\begin{array}{ll}- & \text { ruled by Civil Code (Arts. 1,583, 1,584, 1,589) } \\
- & \text { no clear decision-making tool } \\
- & \text { tries to balance the rights/power between parents } \\
- & \text { applications until the child is } 18 \text { years old }\end{array}$ & 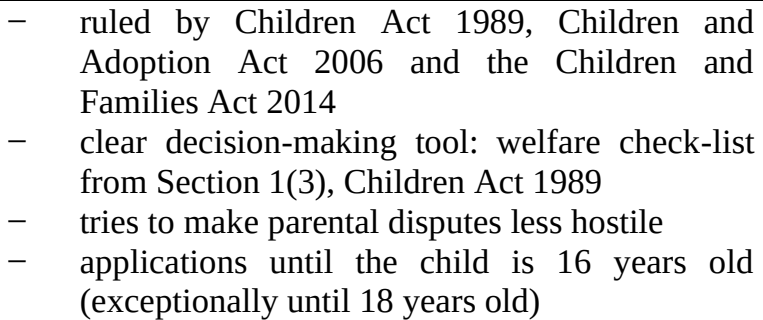 \\
\hline
\end{tabular}

Source: the authors, 2021.

24 'Gillick competence' emerged in the context of medical treatment involving children under 16 and consent. A child is Gillick competent if they present enough maturity and intelligence to understand the nature and implications of the situation. It has been extended to any legal matters in which the child's views and feelings might be important for the decision-making process. For further discussion, see GRIFFITH (2016). 


\section{CHILD CUSTODIAL ARRANGEMENTS AND LEGAL DECISION-MAKING FLOW IN BRAZIL AND ENGLAND}

In both countries, the judicial process regarding child custody after parental separation involves these basic steps: 1) parental separation/divorce; 2) judicial dispute; 3) evaluation; 4) psychosocial report; and 5) judicial decision. The flow of that process is triggered by the occurrence, or not, of parental agreement. Hence, whenever the parents reach an agreement, the case is closed; whenever they do not, the process keeps flowing until it reaches the final judicial decision that will

close the case. Figure 1, at the next page, presents a comparative flowchart demonstrating the judicial custody process after parental separation in Brazil and England. 
Figure 1 - Judicial process in child custody cases after parental separation in Brazil and England (zoom it in for a proper view)

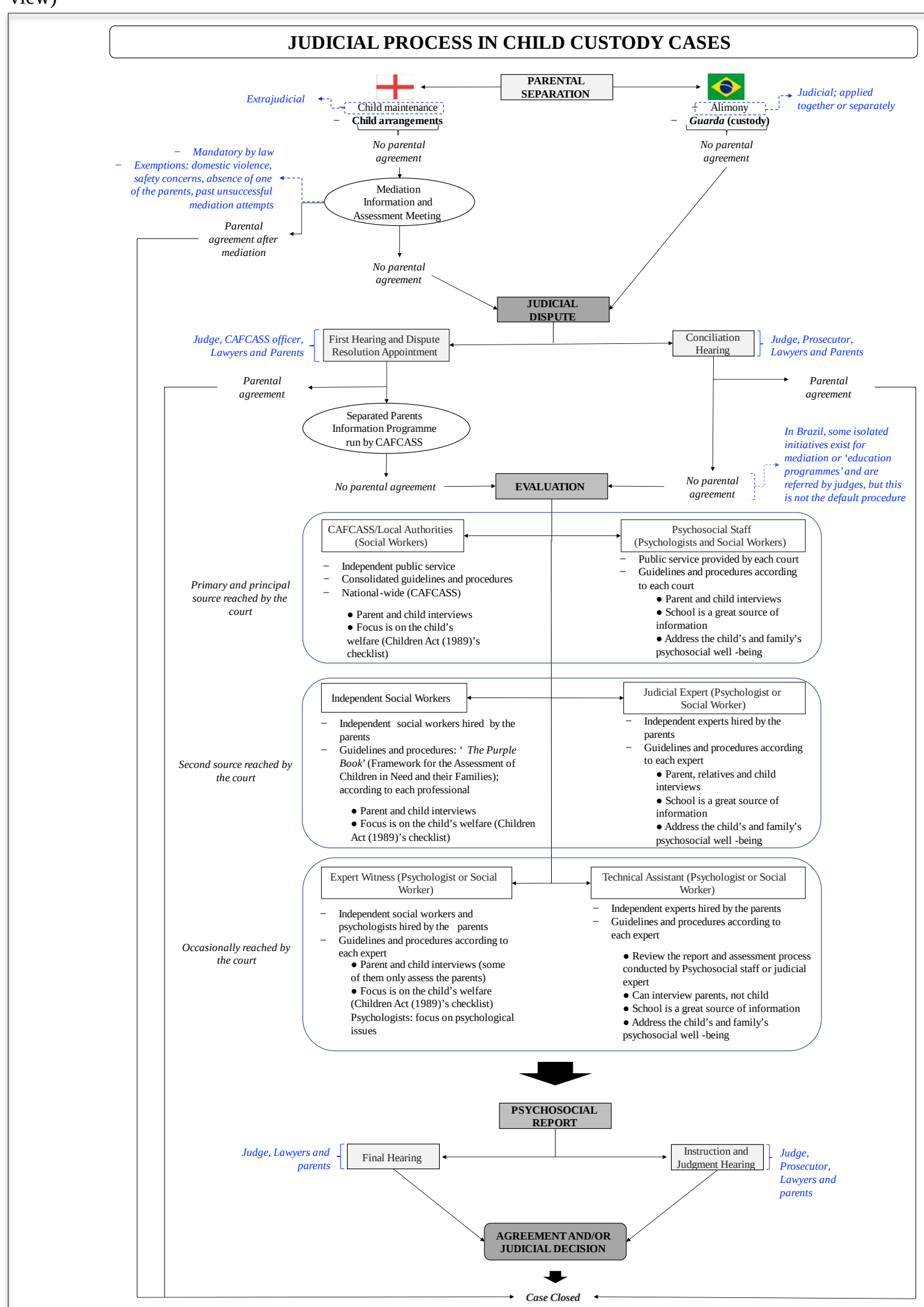

Source: the authors, 2021. 
As seen in Figure 1, after parental separation, if there is no agreement, a judicial dispute regarding child custody may arise. In contrast to Brazil, in England, before applying for a child arrangement order, the parents have to attend a Mediation Information and Assessment Meeting introduced in the English law by the Children and Families Act 2014. In an analogous way, in 2015, the Brazilian New Code of Civil Proceedings created, throughout its Arts. 694 to 696, the need to have a 'Mediation \& Conciliation Hearing' before the court proceedings - but this occurs only after one of the parents has made an application to the court. However, there is not a consensus about whether this hearing is compulsory, or even if a 'forced mediation' would be of much use (TARTUCE, 2016). In reality, some judges just dismiss that hearing and start the proceedings; others proceed with it because the law says it so - also, it is very unlikely that the court will set that hearing if acrimony between the parents is too high. Nonetheless, in Brazil in some courts, parents can be referred to 'educational programmes' that intend to mitigate litigation and help parents reach an agreement.

In both countries, parents (either claimant or defendant) have to present their arguments, proofs and facts in the application but also in a first hearing. 'First Hearing and Dispute Resolution Appointment' (EN) and 'Conciliation' (BR) hearings intend not only to gather arguments, proofs and facts but also to help parents to reach an agreement. In Brazil, the court can designate conciliation hearings as much as the judge thinks is needed. In England, this first hearing has an officer from the British Children and Family Court Advisory and Support Service (CAFCASS) present to assist the court on behalf of the child's best interests. In Brazil, this role will be held by the public prosecutors, as explained before.

In England, if at the First Hearing Dispute Resolution Appointment no agreement is reached, then the court will issue court proceedings with some specific directions. Those directions could include a direction for the appointment of a CAFCASS officer to prepare a report under section 7 of the Children Act 1989. In preparing such a report, the CAFCASS officer must take account of the fact that the child's welfare will be the court's paramount consideration. The CAFCASS officer must consider the factors set out in the welfare checklist in Section $1(3)^{25}$. In Brazil, the evaluation process is conducted by either psychologists or social workers that belong to the court itself - this role is mainly taken by psychologists and there are courts and/or situations in which both professionals can work together. The evaluation is carried by the 'psychosocial service' and their rules, guidelines and

\footnotetext{
25 For further information about the Section 7 report, please see: https://bit.ly/3tJYFQC [Accessed: 14 Apr. 2021].
} 
procedures vary drastically from one state court to another - there are 27 in total. The psychosocial staff will interview the children, their family and also relatives or any other person that might be involved. The Brazilian evaluation process considers inputs from school as a great source of information, and constantly address this in their reports. They also tend to address both the child's and family's well-being.

In a large study with 73 Brazilian and English legal actors (judges, prosecutors, lawyers, psychologists and social workers), Mendes and Ormerod (preprint) found that Brazilian legal actors tend to see the psychosocial evaluation carried in Brazil as 'non-protocol based' due to the fact that each state's court has a particular way to conduct and report the evaluation process and its outcomes. On the other hand, England seems to have a more structured process of evaluation with clear guidelines (set on Children Act 1989, Sections 3, 7 and also by CAFCASS). However, English legal actors might see the CAFCASS' work as 'no-evidence based' due to the fact that CAFCASS officers tend to rely on subjective opinions and views rather than on facts, research or evidence.

Other actors can be involved in the evaluation process. In England, independent social workers can be hired by the parents to conduct the evaluation - as long as the court has agreed to it and granted permission. Usually, they use The Purple Book (Framework for the Assessment of Children in Need and their Families) (UNITED KINGDOM, 2000) but also focus on the welfare checklist and interview the children and their family. There is also the possibility of an expert witness participation (by psychologists or social workers). In this case, every professional has its own guidelines and procedures. In Brazil, there is the figure of 'perito' (i.e., a judicial expert that can be a psychologist or a social worker) who is chosen and designated by the court and paid by the parents. They interview the child, the family, go to the school and address the child's and family's psychosocial well-being. There are also technical assistants (psychologist or social worker); their work is similar to an expert witness' but they only review the assessment conducted by psychosocial staff or judicial expert and they rarely interview the child or, sometimes, the parents.

After the evaluation, a report is made. In England, it is guided by Section 7 of the Children Act 1989 - as mentioned before. In general, the report addresses any specific issues pointed out by the court, the child's wishes and feelings and what the CAFCASS officer understands what are the best interests of the child in that case. In Brazil, the report format and content can vary according to the typical practice of each state court and/or professional.

The report will guide the 'Final Finding Hearing' (EN) and the 'Instruction and Judgment Hearing' (BR), which can lead or not to an agreement between the parents. If they cannot agree, then the judge will make a judicial decision regarding child custody. 


\section{FINAL CONSIDERATIONS}

This paper addressed constraints and process issues regarding child custody cases after parental separation and the BIC in Brazil and England. Each country has its own way of understanding and addressing BIC during the legal process. This applies, for instance, to legal actors' appropriation of the BIC framework. In Brazil, BIC is labelled in the singular and in England in the plural, which may bias legal actors’ perceptions and actions towards BIC in such cases. Moreover, the English legal actors have a clear guidance to understand and assess the BIC (Children Act 1989), while in Brazil BIC is addressed in a less objective way, as it is treated as a general legal principle.

There are also clear differences in the way each country legally binds the relationship between parents and children as well as the continuity of this relationship after the parental separation. In Brazil, the legal binding for that relationship is referred to as 'power' and as 'responsibility' in England. After the marriage breakdown, the Brazilian legal system refers to the child's right to keep 'coexisting' with both parents, while the English one refers to keep the 'contact'.

Some of the main constraints on child custody decision-making are brought about by the ways in which BIC is approached by international law, the type of legal system and the family law characteristics in both countries. In this sense, one should wonder: do those issues impact legal actors' practice? If yes, then why? How do legal actors address them? How do they process them and how these issues impact their practice in child custody cases? On the basis of the review presented above, it is reasonable to expect that Brazilian legal actors might rely more on BIC legislation due to their civil law tradition which makes them more familiar with, and guided by, legislation. In contrast, it is expected that English legal actors would rely more on customary practice. However, Mendes and Ormerod (preprint) found the opposite in a cross-cultural naturalistic decision-making study. Brazilian participants indicated that the law was limited, and insufficient to address the BIC properly. Hence, legal actors' "practice needs to be more open and workarounds need to be applied so they can properly approach the case” (MENDES; ORMEROD, preprint, p. 13). In contrast, English participants reported that, despite being in a more flexible system, they relied heavily on protocols such as the Children Act 1989 welfare checklist. In both countries, these dynamics take place due to the high level of uncertainty that is inherent to child custody cases.

There are also clear differences in the way each country legally binds the relationship between parents and children as well as the continuity of this relationship after parental separation. In Brazil, the legal binding for that relationship is referred to as 'power', and as 'responsibility' in 
England. After the breakdown of a parental relationship, the Brazilian legal system refers to the child's right to keep 'coexisting' with both parents, while the English one refers to 'keeping contact'. In addition, English system seems to be less keen to regulate the family's private interactions than the Brazilian one. It also tends to stimulate as much as possible a self-composition process so the families can find by themselves the best decision for their problems.

Another issue is the appropriation of, guidance about, legal understandings towards BIC and regulations governing the relationship between children and parents as well as the legal system approach to the family and its processes. These are key elements in a child custody case as they can shape the decision-making process. However, another important factor for the decision-making process is frequently disregarded or underestimated by legal actors in both countries: contextual issues such as the family's crisis moment after parental separation. According to the dynamic in which those contextual issues are structured and interact between themselves, the decision-making process can be more or less difficult to understand, assess, and manage. Thus, such dynamics can result in decision making becoming less effective, not only towards a solution but also towards safeguarding the child's best interests. For the decision-making process, it is important to consider how legal actors practicing in post-parental separation disputes are aware of the nature of the crisis. It is important to elucidate how they understand and manage this constraint, and how it impacts on their practice and their attitudes towards BIC.

\section{REFERENCES}

ALANEN, L. Explorations in generational analysis. In: ALANEN, L.; MAYALL, B. (ed.). Conceptualizing child-adult relations. London: Routledge Flamer, 2001. p. 11-22.

ANTUNES, A. L. M. P.; MAGALHÃES, A. S.; FÉRES-CARNEIRO, T. Litígios intermináveis: uma perpetuação do vínculo conjugal? Aletheia, [s. l.], v. 31, p. 199-211, jan./abr. 2010. Available from: https://bit.ly/2Pcz1Vw [Accessed: 15 May 2020].

ARIÈS, P. The discovery of childhood. In: JENKS, C. (ed.). The sociology of childhood: Essential readings. Batsford: Academic and Educational Ltd, p. 27-41, 1982.

ARTIS, J. E. Judging the best interests of the child: Judges' accounts of the tender years doctrine. Law \& Society Review, [s. l.], v. 38, n. 4, p. 769-806, 2004. Available from: https://bit.ly/3nbkl5E [Accessed: 13 Apr. 2021].

BARBOSA, L. P. G.; MENDES, J. A. A.; JURAS, M. M. Dinâmicas disfuncionais, disputa de guarda e alegações de alienação parental: uma compreensão sistêmica. Nova Perspectiva Sistêmica, [s. l.], v. 30, n. 69, p. 78-95, 2021. 
BOWEN, M. De la familia al individuo: La diferenciación del sí mismo en el sistema familiar. Barcelona: Paidós, 1991.

BRADLEY, K. R. Images of childhood in classical antiquity. In: FASS, P. S. (ed.). The Routledge History of Childhood in the Western World. London and New York: Routledge, 2013. p. 17-38.

BRASIL. Constituição da República Federativa do Brasil de 1988. Diário Oficial da União, Brasília, DF, 5 de outubro de 1988. Available from: https://bit.ly/1bJYlGL [Accessed: 13 May 2020].

BRASIL. Lei No 10.406, de 10 de janeiro de 2002. Institui o Código Civil. Diário Oficial da União, Brasília, DF, 11 jan. 2002. Available from: https://bit.ly/1drzx5j [Accessed: 18 Mar. 2020].

BRASIL. Lei $\mathrm{n}^{\circ}$ 13.058, de 22 de dezembro de 2014. Altera os arts. 1.583, 1.584, 1.585 e 1.634 da Lei $\mathrm{n}^{\mathrm{o}}$ 10.406, de 10 de janeiro de 2002 (Código Civil), para estabelecer o significado da expressão "guarda compartilhada” e dispor sobre sua aplicação. Diário Oficial [da] República Federativa do Brasil, Brasília, DF, 22 dez. 2014. Available from: https://bit.ly/2PgV2m9 [Accessed: 8 Mar. 2020].

CANO, D. S. et al. A. As Transições Familiares do Divórcio ao Recasamento no Contexto Brasileiro. Psicol. Reflex. Crit., Porto Alegre, v. 22, n. 2, p. 214-222, 2009. Available from: https://bit.ly/2QvfgsV [Accessed: 25 June 2020].

COSTA, L. F. et al. As competências da Psicologia Jurídica na avaliação psicossocial de famílias em conflito. Psicologia \& Sociedade, Florianópolis, v. 21, n. 2, p. 233-241, maio/ago. 2009. Available from: https://bit.ly/3gvzE85 [Accessed: 18 Mar. 2020].

CRUZ, P. de. Comparative law in a changing world. 3. ed. London: Cavendish, 2007.

CUSTER, L. B. The Origins of the Doctrine of Parens Patriae. Emory L. J., [s. l.], v. 27, n. 1, p. 195-208, 1978. Available from: https://bit.ly/3xlkXdt [Accessed: 15 May 2020].

EMERY, R. E. Renegotiating Family Relationships: Divorce, Child Custody, and Mediation. New York: The Guilford Press, 2012.

FERRARO, J. M. Childhood in medieval and early modern times. In: FASS, P. S. (ed.). The Routledge History of Childhood in the Western World. London and New York: Routledge, 2013. p. 61-77.

GONÇALVES, C. R. Direito civil brasileiro. V. 6 - Direito de família. São Paulo: Editora Saraiva, 2017.

GREENE, S. M. et al. Risk and resilience after divorce. In: WALSH, F. (ed.). Normal family processes: Growing diversity and complexity. New York: The Guilford Press, 2012. p. 112-127.

GRIFFITH, R. What is Gillick competence? Human Vaccines \& Immunotherapeutics, [s. l.], v. 12, n. 1, p. 244-247, 2016. Available from: https://bit.ly/3tNGtFB [Accessed: 14 Apr. 2021]. 
HAMEISTER, B. da R.; BARBOSA, P. V.; WAGNER, A. Conjugalidade e parentalidade: uma revisão sistemática do efeito spillover. Arquivos Brasileiros de Psicologia, [s. l.], v. 67, n. 2, p. 140-155, 2015. Available from: https://bit.ly/3tLHs9B [Accessed: 5 May 2020].

HASHEMI, L.; HOMAYUNI, H. Emotional Divorce: Child's Well-Being. Journal of Divorce \& Remarriage, [s. l.], v. 58, n. 8, p. 631-644, 2017. Available from: https://bit.ly/3vs4zXd [Accessed: 5 May 2020].

HERRING, J. Family Law. 9. ed. London: Pearson, 2019b.

HERRING, J. Family Law. Law Express. 7. ed. London: Pearson, 2019a.

JURAS, M. M.; COSTA, L. F. He was neither a good father nor a good husband: Marital and parental roles in low-income separated families. Psicologia: Teoria e Pesquisa, Brasília, v. 32, n. 5, 2017. Available from: https://bit.ly/3tI8zSI [Accessed: 5 May 2020].

KAGANAS, F. Parental involvement: discretionary presumption. Legal Studies. The Journal of the Society of Legal Scholars, [s. l.], v. 38, n. 4, p. 549-570, 2018. Available from: https://bit.ly/3awZoNC [Accessed: 13 Apr. 2021].

LEHR-LEHNARDT, R.; GUNN, T. J. What's love got to do with it? (Part II): The best interests of the child in international and comparative law. In: JACKSON, T. The Best Love of the Child: Being Loved and Being Taught to Love as the First Human Right. Grand Rapids: Eerdmans, 2011. p. 277-316.

MACIEL, S. A. B.; MENDES, J. A. A.; BARBOSA, L. P. G. Visão sistêmica sobre os pressupostos de alienação parental na prática clínica individual e familiar. Nova Perspectiva Sistêmica, [s. l.], v. 30, n. 69, p. 61-77, 2021.

MCGILLIVRAY, A. Childhood in the Shadow of Parens Patriae. In: GOELMAN, H.; MARSHALL, S. K.; ROSS, S. (ed.). Multiple Lenses, Multiple Images: Perspectives on the Child across Time, Space, and Disciplines. Toronto: University of Toronto Press, 2016. p. 38-72.

MCGOLDRICK, M.; PRETO, N. G; CARTER, B. The expanding family life cycle: Individual, family, and social perspectives. London: Pearson, 2014.

MCGOLDRICK, M.; SHIBUSAWA, T. The family life cycle. In: WALSH, F. (ed.). Normal family processes: Growing diversity and complexity. New York: The Guilford Press, 2012. p. 375-398.

MENDES, J. A. de A. Genealogia, Pressupostos, Legislações e Aplicação da Teoria de Alienação Parental: uma (re)visão crítica. In: SILVA, I. R. da (org.). Debatendo sobre Alienação Parental: Diferentes Perspectivas. Brasília: Conselho Federal de Psicologia, 2019. p. 11-35. Available from: https://bit.ly/3elsXmg [Accessed: 18 Mar. 2020].

MENDES, J. A. de A.; BUCHER-MALUSCHKE, J. S. N. F. Destructive Divorce in the Family Life Cycle and its Implications: Criticisms of Parental Alienation. Psicologia: Teoria e Pesquisa, Brasília, v. 33, n. 1, p. 1-8, 2017. Available from: https://bit.ly/3tLsct3 [Accessed: 10 May 2020]. 
MENDES, J. A. de A.; LORDELLO, S. R.; ORMEROD, T. Uma Proposta de Compreensão Bioecológica do Princípio dos Melhores Interesses da Criança/Adolescente nos Casos de Disputa de Guarda. In: MENDES, J. A. A.; BUCHER-MALUSCHKE, J. S. N. F. (org.). Perspectiva Sistêmica e Práticas em Psicologia: temas e campos de atuação. Curitiba: Editora CRV, 2020. p. 53-58.

MENDES, J. A. de A.; ORMEROD, T. Increasing Uncertainty in Child Custody Cases after Parental Separation: The Role of Context in the Decision-making Process. Family Court Review, [s. l.], preprint.

MENDES, J. A. de A.; ORMEROD, T. The Best Interests of the Child: An Integrative Review of English and Portuguese Literatures. Psicol. estud., Maringá, v. 24, e45021, p. 1-22, 2019. Available from: https://bit.ly/3ndS3rj [Accessed: 18 Mar. 2020].

MEYER, D. R.; CANCIAN, M.; COOK, S. T. The Growth in Shared Custody in the United States: Patterns and Implications. Family Court Review, [s. l.], v. 55, n. 4, p. 500-512, 2017. Available from: https://bit.ly/3gGF3ZM [Accessed: 13 Apr. 2021].

MINUCHIN, P.; COLAPINTO, J.; MINUCHIN, S. Working With Families of the Poor. New York: Guilford Press, 2006.

MOSTEN, F. S.; TRAUM, L. The Family Lawyer's Role in Preventive Legal and Conflict Wellness. Family Court Review, [s. l.], v. 55, n. 1, p. 26-37, 2017. Available from: https://bit.ly/3xiIgoo [Accessed: 8 May 2020].

MOURITSEN, F. Child culture - play culture. In: MOURITSEN, F.; QVORTRUP, J. (ed.). Childhood and Children's culture. Odense: University Press of Southern Denmark, 2002. p. 1442.

MUELLER, B. The Fiscal Imperative and the Role of Public Prosecutors in Brazilian Environmental Policy. Law \& Policy, [s. l.], v. 32, n. 1, p. 104-126, 2009. Available from: https://bit.ly/3dKscnL [Accessed: 14 Apr. 2021].

NATHAN, B. L. Mixing Oil \& Water: Why Child-Custody Evaluations Are Not Meshing with the Best Interests of the Child. Loyola University Chicago Law Journal, [s. l.], v. 46, n. 1, p. 865911, 2015. Available from: https://bit.ly/3xicecd [Accessed: 5 May 2020].

NOROZI, S. A.; MOEN, T. Childhood as a Social Construction. Journal of Educational and Social Research, [s. l.], v. 6, n. 2, p. 75-80, 2016. Available from: https://bit.ly/2QuoGFd [Accessed: 18 Mar. 2020].

POJANOWSKI, Jeffrey A. Reading Statutes in the Common Law Tradition. Virginia Law Review, [s. l.], v. 101, p. 1357-1424, 2015. Notre Dame Legal Studies Paper No. 1438. Available from: https://ssrn.com/abstract=2485599 [Accessed: 14 Apr. 2021].

PONCIANO, E. L. T.; FÉRES-CARNEIRO, T. Conjugalidade, parentalidade e separação: repercussões no relacionamento pais e filhos(as). Psicologia em estudo, Maringá, v. 22, n. 2, p. 277-287, 2017. Available from: https://bit.ly/3gCeftN [Accessed: 20 May 2020]. 
REECE, H. Leaping without Looking. In: LECKEY, R. (ed.). After Legal Equality: Family, Sex, Kinship. Abingdon: Routledge, 2015. p. 115-133.

RÖDER, B. Prehistoric households and Childhood. Growing up in a daily routine.

In: CRAWFORD, S.; HADLY, D. M.; SHEPHERD, G. (ed.). The Oxford Handbook of the Archaeology of Childhood. Oxford: Orford University Press, 2018. p. 123-147.

ROSA, V. de C. A base de cálculo da pensão alimentícia segundo a jurisprudência brasileira. Conteúdo Jurídico, Brasília, v. 7, n. 421, p. 58-91, 2015. Available from: https://bit.ly/3xsRUoL [Accessed: 14 Apr. 2021].

ROSMANINHO, T. O conflito entre ex-cônjuges e o divórcio emocional. In: SOTTOMAYOR, M. C.; ALMEIDA, M. T. F. de (ed.). E foram felizes para sempre...? Uma análise crítica do novo regime jurídico do divórcio. Coimbra: Coimbra Editora, 2010. p. 309-311.

SKINNER, C. Child maintenance in the United Kingdom. European Journal of Social Security, [s. l.], v. 14, n. 4, p. 231-251, 2012. Available from: https://bit.ly/3tPTzlK [Accessed: 14 Apr. 2021].

SKINNER, C. Fathers, child maintenance and contact. Nemesis, [s. l.], n. 1, p. 5-13, 2002. Available from: https://bit.ly/3xlTQze [Accessed: 14 Apr. 2021].

SWARTZ, N. P. A judicial appraisal on the best interest of the child standard with regard to custody and access decisions on divorce: a constitutional developmental imprint. Journal of Social Science Research, [s. l.], v. 11, n. 2, p. 2.401-2.414, 2017. Available from: https://bit.ly/3gyfrOI [Accessed: 13 Apr. 2021].

TARTUCE, Fernanda. O novo marco legal da mediação no direito brasileiro. 2016. Available from: https://bit.ly/3sJyoC7 [Accessed: 14 Apr. 2021].

UNITED KINGDOM. Children and Families Act 2014 [online]. London: The Stationery Office, 2014. Available from: https://bit.ly/3dK3KCS [Accessed: 18 Mar. 2020].

UNITED KINGDOM. Department of Health. Framework for the Assessment of Children in Need and their Families. London: Stationery Office, 2000. Available from: https://bit.ly/3xqZtwb [Accessed: 23 May 2020].

UNITED KINGDOM. UK Public General Acts. Children Act 1989 [online]. London: The Stationery Office, 1989. Available from: https://bit.ly/3gCfpWb [Accessed: 18 Mar. 2020].

VENTURI, E. Transação de direitos indisponíveis? Revista de Processo, [s. l.], v. 251, p. 391-426, jan. 2016. Available from: https://bit.ly/2RO68Qq [Accessed: 5 May 2020].

WOLFF, L. Childhood and the enlightenment: The complications of innocence. In: FASS, P. S. (ed.). The Routledge History of Childhood in the Western World. London and New York: Routledge, 2013. p. 78-99. 
WURTZ, J. Childhood as a philosophical means to a political end: liberalism, stability, and the deficiency model of childhood. 2020. 209 f. Thesis (Doctor in Philosophy) - University of Memphis, Memphis, 2020. Available from: https://bit.ly/3xkvl5c [Accessed: 14 Apr. 2021].

ZWEIGERT, K.; KÖTZ, H. An Introduction to Comparative Law. Oxford: Oxford University Press, 1998. 